\title{
THE ROLE OF LINEAR STRUCTURES IN AGRICULTURAL LANDSCAPE IN THE MAITENANCE OF XEROTHERMIC SPECIES
}

\author{
Joanna Czarnecka \\ Department of Ecology, Maria Curie-Skłodowska University, Akademicka 19, 20-033 Lublin, Poland \\ e-mail: a_czarnecki@wp.pl
}

Received: 01.10.2011

\begin{abstract}
The aim of the study was to evaluate the role of different types of linear structures in the preservation of four xerothermic species (Centaurea scabiosa, Euphorbia cyparissias, Melampyrum arvense, and Salvia verticillata) and two weeds (Euphorbia exigua and Thymelaea passerina). Observations were conducted in the agricultural landscape of Western Volhynia with fields of different land use intensity (a large-scale farming system and small traditional arable fields). The total length of the studied structures was $4760 \mathrm{~m}$ and the following five categories of structures were distinguished: field road verges adjacent to large (1) and small fields (2), field margins between the patches of xerothermic grasslands as well as large (3) or small fields (4) and balks (5). The distribution and abundance of species mentioned above were recorded there. The survey showed that linear habitats are not suitable for all the studied species; margins between arable fields and grasslands were the most important habitats for both grassland and weed species. Factors responsible for their abundance and distribution along these margins included the following: type of farming system, exposure of the margin, and soil moisture. Grassland species occupied habitats adjacent to small traditional fields with other than southern exposure; weeds were more abundant in drier microhabitas.
\end{abstract}

Key words: xerothermic grasslands, linear structures, matrix-patch-network model, marginal habitats

\section{INTRODUCTION}

Changes in agricultural practices, e.g. farm specialisation, consolidation of farm units, removal of non-cropped field boundaries, mechanisation and agrochemical use, and also abandonment of some fields have reduced biodiversity of agricultural landscape (B e n ton et al. 2003; G a b a et al. 2010; U e mat $\mathrm{su}$ et al. 2010). Small areas favourable for vegetation in agricultural landscape (called patches, e.g. grasslands, abandonments or forest islands) are submer- ged in an unfavourable environment (matrix - arable fields) and connected by the network of corridors (linear structures) (C o r bit et al. 1999; Le Coe ur et al. 2002; M arshal1, 2002). Linear structures (e.g. field margins, ditches or road verges) play the role of refuges and ecological corridors for different groups of organisms, and their importance is well known and widely appreciated (M r shal1, 1989; Rew et al. 1996; Kleijn and Verbeek, 2000; Den is ow and Wrzesién 2007; Hawes et al. 2010).

The aim of the study was to evaluate the role performed by different types of linear structures in the agricultural landscape of Western Volhynia (the region according to $\mathrm{S} \mathrm{z}$ a fer and $\mathrm{Zarzycki}$, 1972) in the preservation of selected xerothermic species. The main problem in the protection of xerothermic grasslands is their overgrowing by brushwood as a result of abandonment and of the natural process of succession ( $\mathrm{De}$ $\mathrm{n}$ i s o w et al. 2008). Grassland species disappear because of changes in their habitat, and linear structures can potentially play the role of refuges for this group of species.

The more specific goals can be formulated in the following way:

1. Analysis of the spatial distribution of selected xerothermic species and weeds along linear structures.

2. Comparison of the pattern of distribution of two ecological groups of species with different life strategies and life-history traits (grassland and selected weed species) along linear structures.

\section{MATERIALS AND METHODS}

The survey was conducted in the agricultural landscape surrounding two ecological units, "Korhynie" and "Zurawce", which constitute a part of the Natura 2000 site Żurawce (PLH060029; Western Volhynia) in 
the growing season of 2007. They host xerothermic grasslands on calcareous soil which are important orchid sites (habitat 6210). The grasslands are partly overgrown by brushwood (Prunus spinosa L., Cornus sanguinea L., Juniperus communis L. and other taxa characteristic of the Rhamno-Prunetea class). They are surrounded by arable fields with different land use intensity: large-scale fields in the vicinity of "Żurawce" and small traditional fields located close to "Korhynie" (Fig. 1). The total length of the studied linear structures was $4760 \mathrm{~m}$. They were divided into $20 \mathrm{~m}$ long stretches, later called plots $(\mathrm{N}=238)$. It was possible to distinguish five types of linear structures there: road verges adjacent to large (n $=58$, where $\mathrm{n}$ is the number of plots) and small fields ( $\mathrm{n}$ $=65)$, field margins of small $(n=37)$ or large fields $(n$ $=67$ ) adjacent to the patches of xerothermic grasslands. The last analysed type of linear structures were balks ( $\mathrm{n}$ $=13$ ). Balks create a dense network only in the part of the study area where small traditional arable fields were located (Fig. 1). The number of plots representing the vegetation of balks was low in comparison to the other types of linear structures and in some analysis they were included into one group with plots representing the neighbourhood of the small arable fields. Ten plots had been earlier excluded from the analysis because they could not be classified as linear structures. They were located at the sites where grasslands were adjacent to abandoned lands (in the case of margins) or to grassland (in the case of field roads).

The abundance of four grassland species (Centaurea scabiosa L., Euphorbia cyparissias L., Melampyrum arvense L., and Salvia verticillata $\mathrm{L}$.) and twelve weeds (all of them are listed in Fig. 3) was recorded in each study plot. Detailed data on the distribution and abundance of two weed species - Euphorbia exigua L. and Thymelea passerina (L.) Coss. \& Germ., were used later. The following abundance scale was used: 1 - 1-10 individuals; $2-11-50$ individuals; 3 - more than 50 individuals. Some features of the habitat at each plot along the margin of the ecological unit "Korhynie" were also recorded: width of the margin (it ranges between 0.25 and $1 \mathrm{~m}$; it was $2 \mathrm{~m}$ in one case only), exposure (southern versus the other types), type of farming system in the vicinity of the margin (large-scale versus traditional farming system), percentage coverage of herb layer, and soil moisture. A four-digit scale (1-4) was used for assessing soil moisture, where 1 means the driest habitats and 4 the moistest ones.

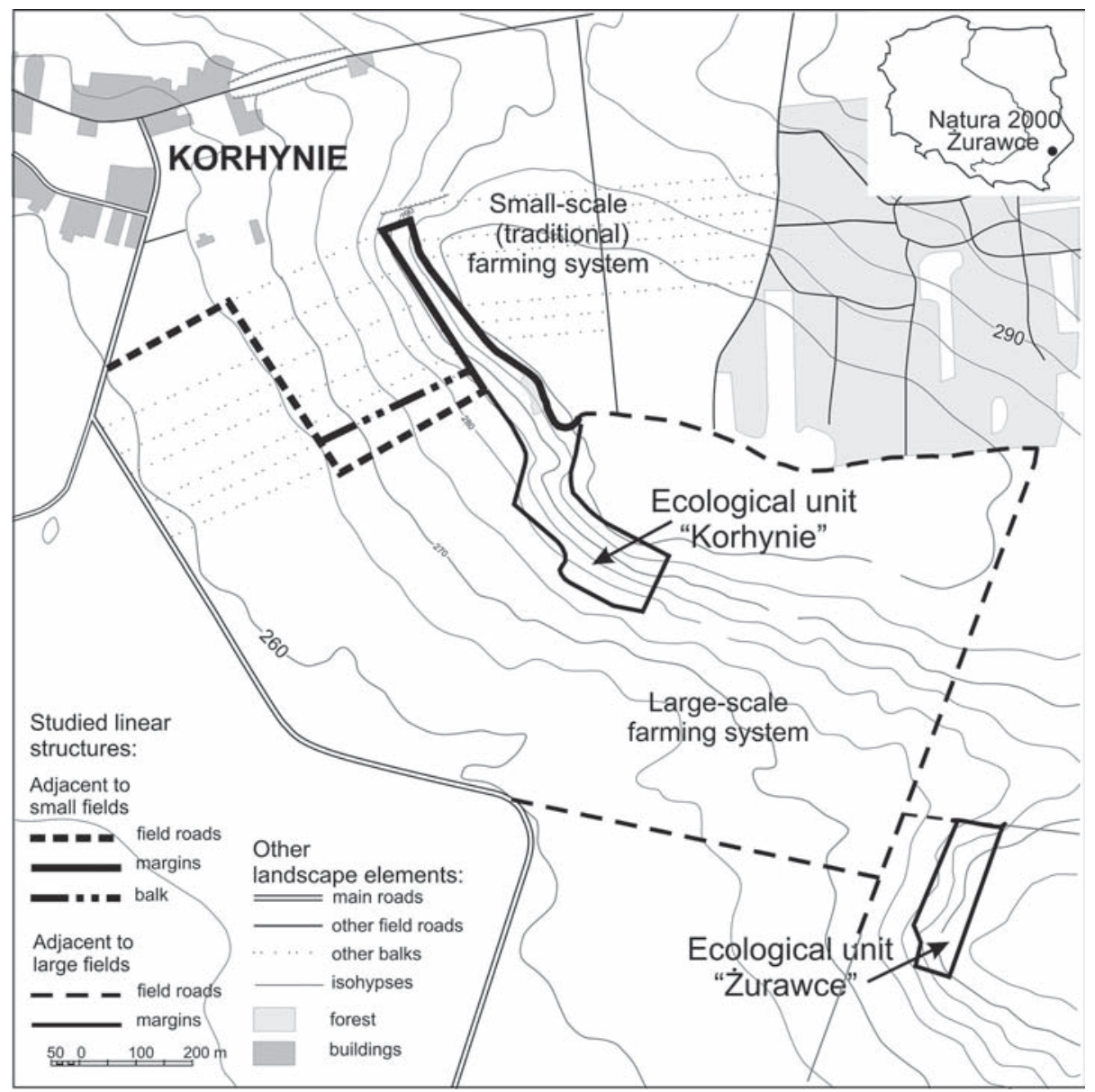

Fig. 1. Arrangement of landscape elements at the study site. 
Distribution of selected species was analysed with the $x^{2}$ test ( $\left.\mathrm{Eomnicki}, 2003\right)$. The share of plots with the presence of specific species in the total pool of samples was treated as the expected value in all cases. The Canonical Correspondence Analysis (CCA) of species abundance connected with the main habitat factors was conducted with the use of the Canoco 4.5 software (T e r B ra ak and Š mil a u e r, 2002).

\section{RESULTS}

The frequency (measured as the share of plots occupied by a specific species) of the studied grassland species varied between 14\% (Euphorbia cyparissias) and $29 \%$ (Salvia verticillata). Weed species were less frequent: in the case of Thymelaea passerina the share of plots with this species present was only $3 \%$ (Fig. 2, Table 1).

The share of plots with the presence of the analysed species varied among the different categories of linear structures. Two main features of the analysed habitats seemed to be responsible for species distribution: the type of the linear structure (road verge, margin or balk), and the neighbourhood of the structure (small and large arable fields). Grassland species were much more abundant along the margins between xerothermic grasslands and arable fields. The neighbourhood of the linear structure seems to be relatively less important. Only Centaurea scabiosa and Melampyrum arvense seemed to be much more connected with the habitats adjacent to small fields (Table 1).

Margins between arable fields and grasslands were the most suitable type of linear structures for all the studied species; but along these margins, the distribution of species and their abundance also varied. The Canonical Correspondence Analysis (CCA) helped to isolate factors responsible for the spatial distribution of species (Fig. 3, Table 2). Statistically significant were the following environmental variables: type of farming system, exposure of the margin, and soil moisture. Grassland species occupied habitats adjacent to small traditional fields with other than southern exposures - they avoided sites with extreme conditions which were preferred by weeds, mainly thermophilous and calciphlious species of the sub-Mediterranean type of range, e.g. Caucalis platycarpos L. and Conringia orientalis (L.) Dumort.

Table 1.

Frequency of species in plots of different type of linear structures and results of $\chi^{2}$ test; *plots along the balk were included into the "small fields" group. The share of plots with the presence of specific species in the total pool of plots $(\mathrm{N}=228)$ was treated as the expected value in all cases

\begin{tabular}{|c|c|c|c|c|c|c|c|c|c|}
\hline \multirow{2}{*}{ Species } & \multirow{2}{*}{ Total } & \multicolumn{4}{|c|}{ Type of linear structure } & \multicolumn{4}{|c|}{ Neighbourhood } \\
\hline & & Margins & Road verges & $x^{2}$ & $P$ & Large fields & Small fields* & $x^{2}$ & $P$ \\
\hline Centaurea scabiosa & 16 & 22 & 12 & 3.83 & NS & 8 & 25 & 10.56 & $<0.01$ \\
\hline Euphorbia cyparissias & 14 & 26 & 5 & 17.60 & $<0.001$ & 13 & 16 & 0.47 & NS \\
\hline Melampyrum arvense & 20 & 34 & 9 & 17.17 & $<0.001$ & 10 & 30 & 11.02 & $<0.001$ \\
\hline Salvia verticillata & 29 & 59 & 5 & 55.000 & $<0.001$ & 30 & 26 & 0.24 & NS \\
\hline Euphorbia exigua & 14 & 30 & 1 & 35.70 & $<0.001$ & 10 & 19 & 2.95 & NS \\
\hline Thymelaea passerina & 3 & 6 & 1 & 5.25 & $<0.05$ & 3 & 3 & 0.00 & NS \\
\hline
\end{tabular}

Table 2.

Results of forward selection of environmental variables and Monte Carlo permutation test

\begin{tabular}{lccc}
\hline \multicolumn{1}{c}{ Variable } & Lambda-A & F & $P$ \\
\hline Large-scale farming system & 0.25 & 6.31 & 0.002 \\
Southern exposure & 0.09 & 2.45 & 0.006 \\
Soil moisture & 0.08 & 2.02 & 0.022 \\
Width of margin & 0.03 & 0.96 & 0.488 \\
Coverage of herb layer & 0.03 & 0.79 & 0.702 \\
\hline
\end{tabular}



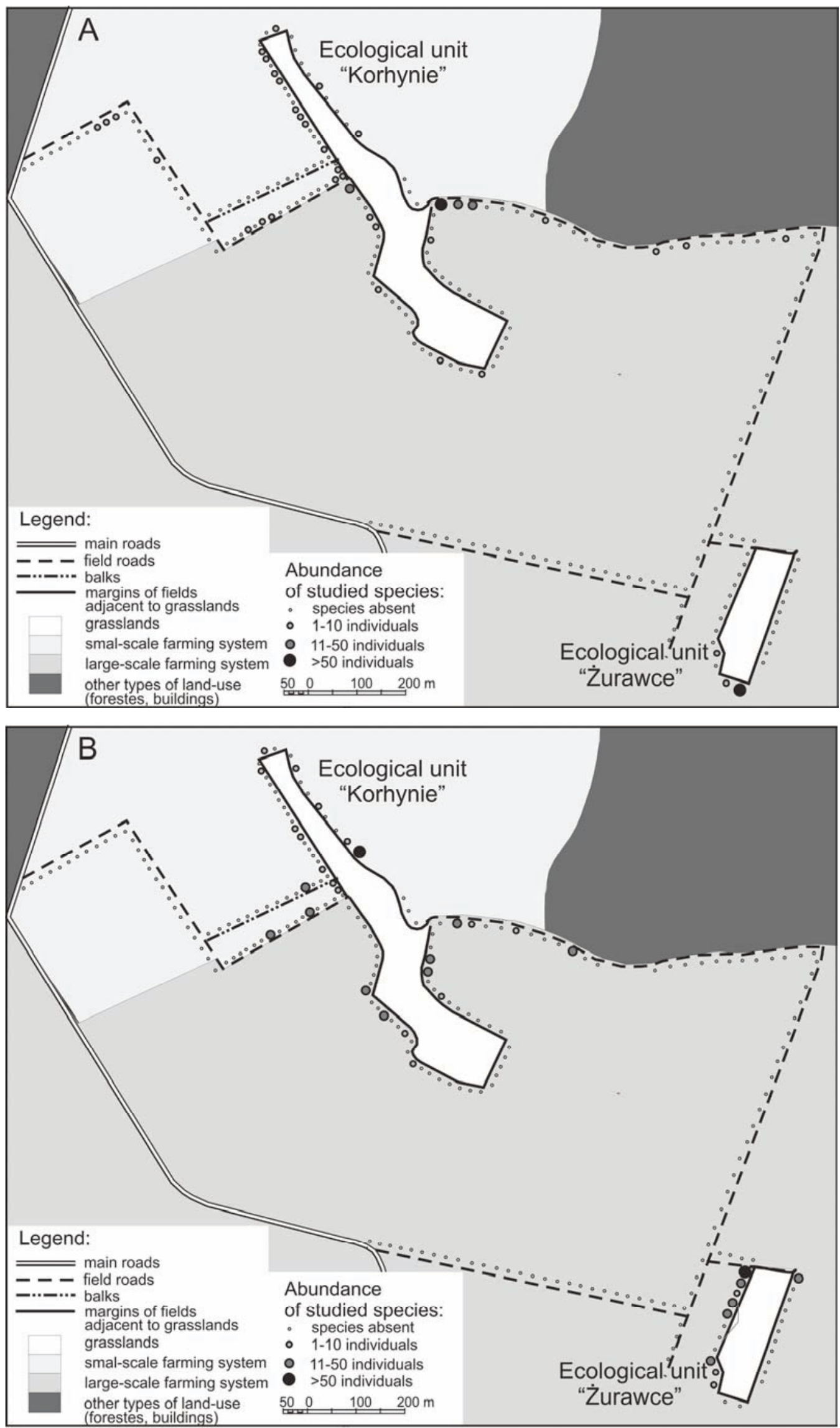

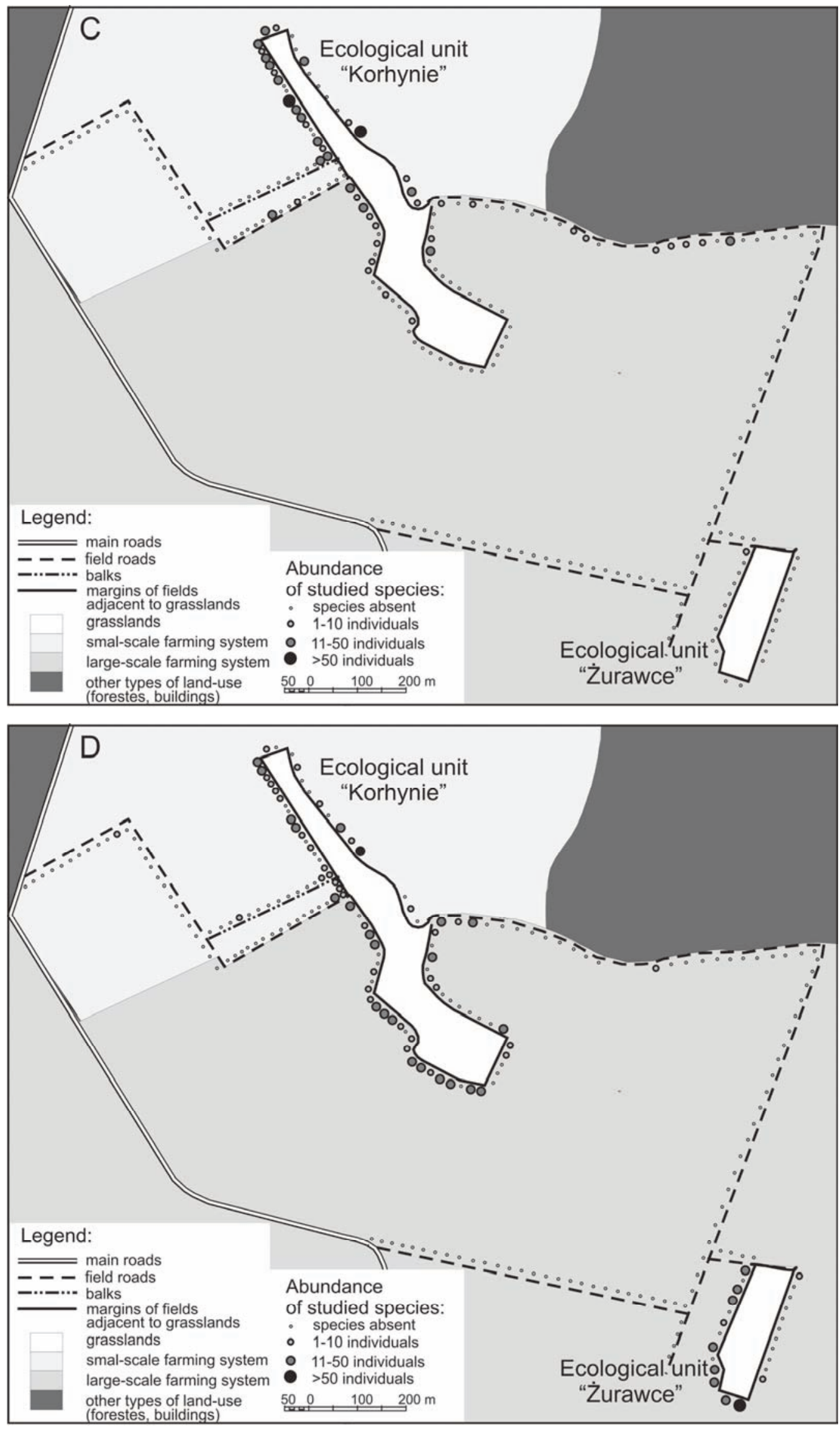

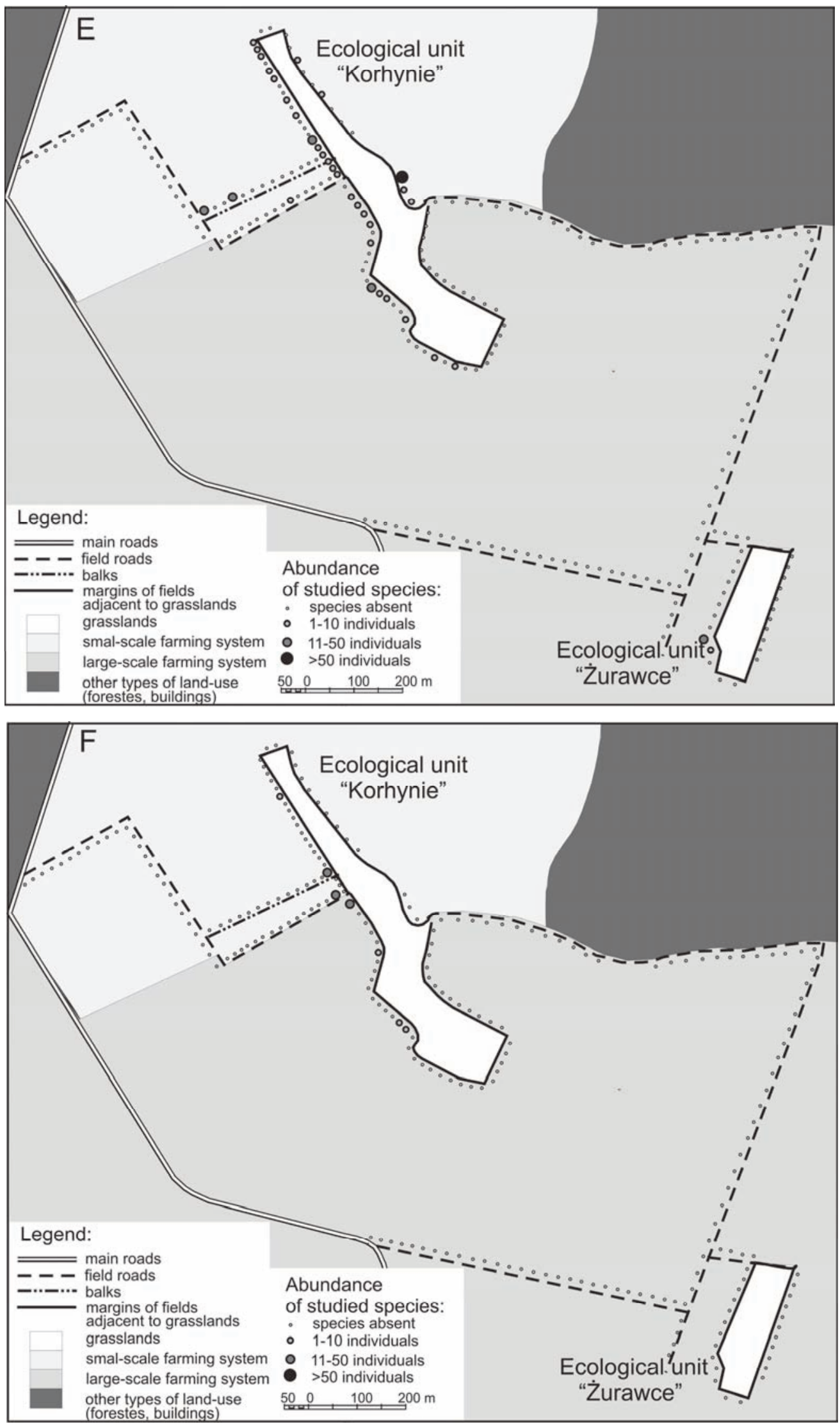

Fig. 2. Distribution of the studied species along different types of linear structures: A - Centaurea scabiosa; B - Euphorbia cyparissias; C - Melampyrum arvense; D - Salvia verticillata; E - Euphorbia exigua; F - Thymelaea passerina. 


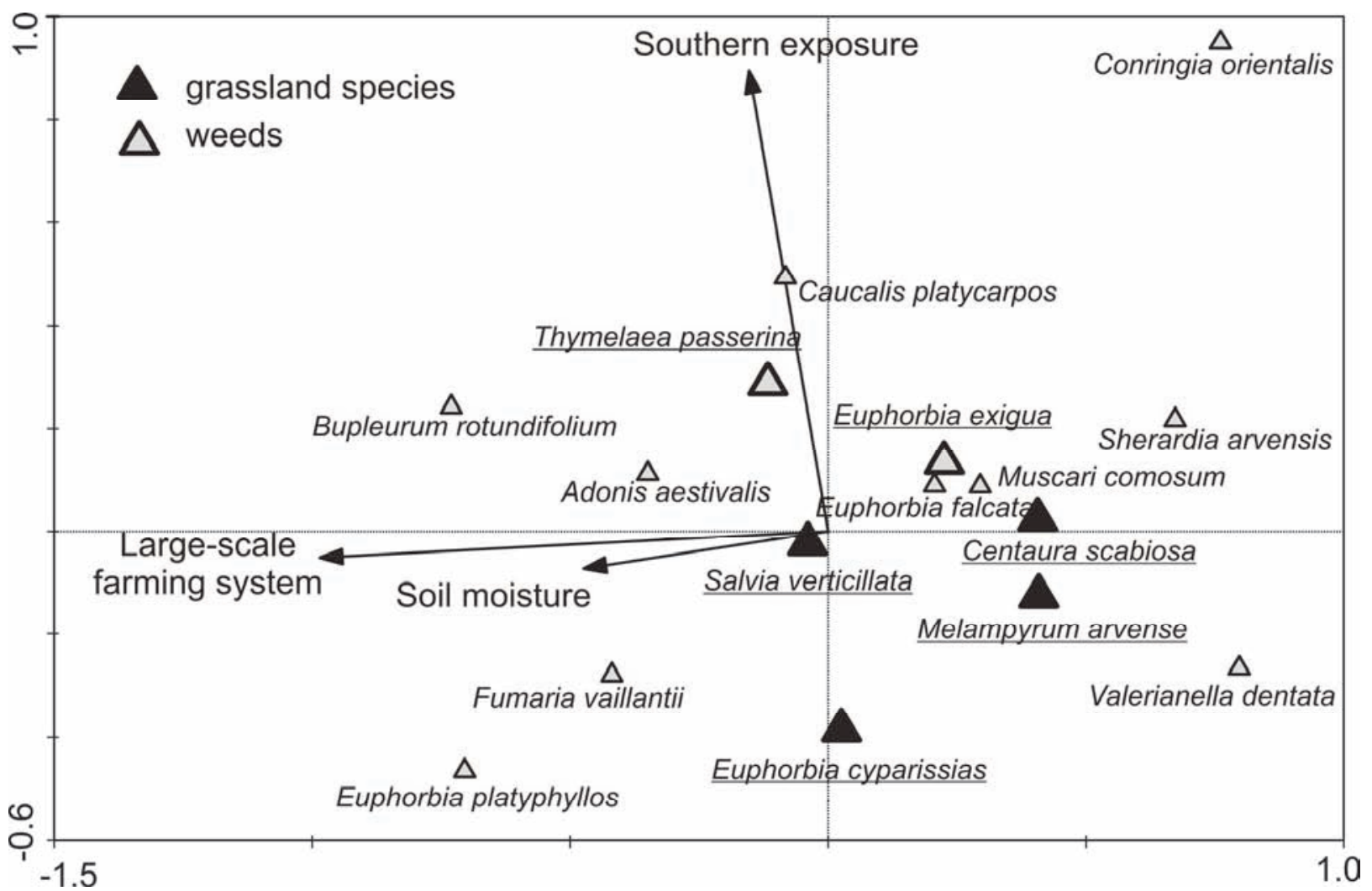

Fig. 3. Results of CCA analysis of the abundance of species and environmental variables. Eigenvalues; axis $1-0.252$; axis 2 -0.104 , sum of all eigenvalues -2.976 , sum of all canonical eigenvalues -0.482 . Symbols for six analysed species are enlarged and their names are underlined.

\section{DISCUSSION}

It is sometimes underlined that linear structures can serve as a suitable environment for many groups of species, e.g. grassland and herbaceous woodland species (Corbit et al. 1999; Tanghe and God e fro id, 2000; C z a r n e c k a, 2006). Other works have proved that in some cases they are inappropriate for these plants. Fencerows appeared not to be effective corridors for some woodland species (F r i t s and Merriam, 1993), and road verges seemed not to be adequate substitute habitats for the majority of species typical of semi-natural grasslands in Norway (H a m r e et al. 2010). The present study confirms the latter observation mentioned above. Grassland species are concentrated mainly in places close to the source of diaspores, which is located in the patches of grasslands protected as the ecological units "Korhynie" and "Żurawce" (source populations, according to Pulliam, 1988). The main factor which slows down the process of colonization of linear structures in the studied agricultural landscape is the limited dispersal ability of the studied species. Grassland species, despite their various dispersal modes (anemochory in the case of Centarurea scabiosa, myrmecochory - Euphorbia cyparissias and Melampyrum arvense, and barochory in the case of Salvia verticillata), do not effectively disperse for long distances. It is widely known that even in the case of species with adaptations to anemochory, which is one of the most effective dispersal modes, the majority of seeds are placed in the close vicinity of the mother plant (V e r k a a r et al. 1983; K li in k h a $\mathrm{m}$ e $\mathrm{r}$ et al. 1988). The present study showed that some weeds exhibit the distribution pattern similar to grassland species, although the reasons of their disappearance are different (e.g. modernisation of agriculture and the increasing use of herbicides). Although their abundance is even lower than in the case of grassland species, they also prefer margins between arable fields and grasslands. These results point to the particularly high importance of this type of linear structures for the maintenance of many groups of species connected with the man-shaped landscape. The role of field road verges is much smaller.

\section{Acknowledgements}

I would like to thank two reviewers for comments and valuable remarks on this manuscript. 


\section{REFERENCES}

Benton T.G., Vickery J.A., Wilson, J.D., 2003. Farmland biodiversity: is habitat heterogeneity the key? Trends Ecol. Evol. 18: 182-188.

Corbit M., Marks P.L., Gardescu S., 1999. Hedgerows as habitat corridors for forest herbs in central New York. USA. J. Ecol. 87: 220-232.

$\mathrm{Czarnecka} \mathrm{J.,} \mathrm{2006.} \mathrm{Roasides} \mathrm{as} \mathrm{plant} \mathrm{diversity} \mathrm{refuges} \mathrm{in}$ agricultural landscape. Ecol. Quest. 7: 37-46.

Denisow B., Wrzesień M., 2007. The anthropogenic refuge areas for bee flora in agricultural landscape. Acta Agrobot. 60: 147-157.

Denisow B., Wrzesień M., Cwener A., 2008. The estimation of Adonis vernalis populations in chosen patches of Lublin Upland. Acta Agrobot. 61: 3-11.

Fritz R., Merriam G., 1993. Fencerow habitats for plants moving between farmland forests. Biol. Conserv. 64: 141-148.

Gaba S., Chauvel B., Dessaint F., Bretagnolle V., Petit S., 2010. Weed species richness in winter wheat increases with landscape heterogeneity. Agric. Ecosyst. Environ. 138: 318-323.

Hamre L.N., Halvorsen R., Edwardsen A., Rydgren K., 2010. Plant species richness, composition and habitat specificity in a Norwegian agricultural landscape. Agric. Ecosyst. Environ. 138: 189-196.

Hawes C., Squire G.R., Hallett P.D., Watson C.A., Young M., 2010. Arable plant communities as indicators of farming practice. Agric. Ecosyst. Environ. 138: 17-26.

Kleijn D., Verbeek M., 2000. Factors affecting the species composition of arable field boundary vegetation. J. Appl. Ecol. 37: 256-266.

Klinkhamer P.G.L., De Jong T.G., van der Meijden E., 1988. Production, dispersal and predation of seeds in the biennal Cirsium vulgare. J. Ecol. 76: 403-414.

Le Coeur D., Baundry J., Burel F., Thenail C., 2002. Why and how we should study field boundary biodiversity in an agrarian landscape context. Agric. Ecosyst. Environ. 89: 23-40.

Łomnicki A., 2003. Wprowadzenie do statystyki dla przyrodników. Wyd. Nauk. PWN, Warszawa: 261. (in Polish).

Marshall E.J.P., 1989. Distribution patterns of plants associated with arable field edges. J. Appl. Ecol. 26: 247257.

Marshall E.J.P., 2002. Introducing field margin ecology in Europe. Agric. Ecosyst. Environ. 89: 1-4.

P ulli a m H.R., 1988. Sources, sinks and population regulations. Am. Nat. 31: 145-172.

Rew L.J., Froud-Williams R.J., Boatman N.D., 1996. Dispersal of Bromus sterilis and Anthriscus silvestris seed within arable fields margins. Agric. Ecosyt. Environ. 59: 107-114.
Szafer W., Zarzycki K., (red.). 1972. Szata roślinna Polski. Państwowe Wydawnictwo Naukowe, Warszawa. (in Polish).

Tanghe M., Godefroid S., 2000. Road verge grasslands in southern Belgium and their conservation value. Fragm. Flor. Geobot. 45: 147-163.

Ter Braak C.J.F., Šmilauer P., 2002. CANOCO Reference manual and CanoDraw for Windows User's guide: Software for Canonical Community Ordination (version 4.5) Microcomputer Power, Ithaca, NY, USA: 500 .

Uematsu Y., Koga T., Mitsuhasi H., Ushima$\mathrm{r} u$ A ., 2010. Abandonment and intensified use of agricultural land decrease habitats of rare herbs in semi-natural grasslands. Agric. Ecosyst. Environ. 135: 304-309.

Verkaar H.J., Schenkeveld A.J., van der Klashorst M.P., 1983. The ecology of short lived forbs in chalk grasslands: dispersal of seeds. New. Phytol. 95 : $335-344$.

\section{Znaczenie struktur liniowych krajobrazu rolniczego dla zachowania gatunków kserotermicznych}

\section{Streszczenie}

Celem badań, przeprowadzonych w krajobrazie rolniczym Wołynia Zachodniego (otoczenie obszaru Natura 2000 Żurawce, PLH060029), było określenie znaczenia struktur liniowych dla zachowania wybranych gatunków muraw kserotermicznych (Centaurea scabiosa, Euphorbia cyparissias, Melampyrum arvense i Salvia verticillata) oraz ciepłolubnych chwastów (Euphorbia exigua i Thymelea passerina). Oceniono rozmieszczenie i liczebność powyższych gatunków wzdłuż struktur liniowych o łącznej długości 4760 m, wśród których wyróżniono: miedze, pobocza polnych dróg przylegające do niewielkich tradycyjnych pól uprawnych i upraw wielkoobszarowych oraz obrzeża pól uprawnych (marginesy) sąsiadujące z murawami kserotermicznymi. Badania wykazały, że analizowane struktury liniowe nie są dogodnym siedliskiem dla badanych gatunków. Największe znaczenie spośród nich mają marginesy między murawami i polami uprawnymi. Najistotniejsze czynniki siedliskowe odpowiedzialne za rozmieszczenie i liczebność analizowanych gatunków wzdłuż tych marginesów to: rodzaj prowadzonej gospodarki rolnej (wielkoobszarowa i tradycyjna), ekspozycja oraz wilgotność gleby. Gatunki murawowe występują $\mathrm{w}$ mikrosiedliskach sąsiadujących $\mathrm{z}$ niewielkimi polami o tradycyjnym typie gospodarowania i wystawie innej niż południowa. Mikrosiedliska o najbardziej ekstremalnych warunkach, skrajnie suche, są zasiedlane głównie przez ciepłolubne i wapieniolubne gatunki chwastów o przyśródziemnomorskim typie zasięgu. 